\title{
Effect of Geographic Location and Age on Levels of Some Biochemical Parameters of Ewes in Southern of Iraq
}

\author{
Waleed Y. Kassim¹, Murthda F. AL-Hellou² \\ ${ }^{1}$ Department of Animal Production, College of Agriculture, University of Basrah, Basrah, Iraq \\ ${ }^{2}$ Department of Biology, College of Education/Qurna, University of Basrah, Basrah, Iraq \\ Email: waleed.kassim95@gmail.com
}

How to cite this paper: Kassim, W.Y. and AL-Hellou, M.F. (2018) Effect of Geographic Location and Age on Levels of Some Biochemical Parameters of Ewes in Southern of Iraq. Journal of Biosciences and Medicines, 6, 21-29.

https://doi.org/10.4236/jbm.2018.611003

Received: September 20, 2018

Accepted: November 13, 2018

Published: November 16, 2018

Copyright ( $) 2018$ by authors and Scientific Research Publishing Inc. This work is licensed under the Creative Commons Attribution International License (CC BY 4.0).

http://creativecommons.org/licenses/by/4.0/

\begin{abstract}
A total of one hundred and ten healthy dry ewes of Arabi sheep diffusive in three geographic locations in the north of Basrah (AL-Qurna, Al-Midaina and Al-Uazair) were divided into three different age groups: $<1$ year old, between 1 - 3 years old and $>3$ years old, to investigate the influence of geographic location and age on the concentration of some biochemical parameters of sheep in the south of Iraq. The results showed significant $(P<0.05)$ changes among geographic locations in some biochemical parameters such as cholesterol, glucose, estridol and growth hormone concentrations. No significant differences were presented in concentrations of total protein, albumin, $\mathrm{Fe}$, phosphorus, ascorbic acid, LH, T3 and T4 hormones in the blood of ewes in different geographic locations. The concentrations of cholesterol, T3 and T4 hormones decreased significantly $(\mathrm{P}<0.05)$, while, the concentrations of glucose and estradiol hormone increased significantly $(\mathrm{P}<0.01)$ in adult ewes compared with younger ewes.
\end{abstract}

\section{Keywords}

Geographic Location, Age, Biochemical Parameters, Ewes

\section{Introduction}

The zone of Basrah province is characterized by semi-arid with high temperature conditions in summer and a few fall down rain in winter, so, it is suffering in cover plant. Depended on the FAO report, sheep population in Iraq was 6,750,000 heads in 1999 (FAO, 2003). The Arabi breed is the main domestic sheep in south of Iraq, which follows the tailed carpet wool sheep and characte- 
rized by the smallest size of local breeds in Iraq [1]. This kind of breed is adaptable to the difficult environmental conditions and also tolerance to the diseases. The Arabi sheep form $20 \%$ of the local sheep population [2], more primary formation about Arabi sheep is presented in Table 1.

The metabolic profiles of the sheep, containing serum mineral, hormones and biochemical parameters were important to determine both health conditions, feed status and metabolic conditions, which are led to improve the production and reproduction of animals [3] [4]. On the other hand, the physiologic and pathologic trails can be better when values of blood parameters were around within natural rang [5]. Blood parameters are changed by many factors, including management, feeding system, age, sex, breed, environment conditions, etc. [6] [7].

Many studies were reported that the biochemical parameters values vary between young and adult sheep and these values are changing with age [4] [8] [9].

Based on our information, there are a few studies about the influence of the geographic location, especially in the north of Basrah area, therefore, the aim of this study was shown the effect of geographic location and age of sheep on the levels of some biochemical parameters in the south of Iraq.

\section{Materials and Methods}

The study was conducted in the south of Iraq in Basrah province $\left(30^{\circ} 30^{\prime} \mathrm{N}\right.$ $47^{\circ} 49^{\prime} \mathrm{E}$ with about $181 \mathrm{~km}^{2}$ of area) in January of 2018 to investigate the influence of the geographic location and age on the concentration of some biochemical parameters of sheep in the south of Iraq. Three geographic locations sites in the north of Basrah (AL-Qurna, Al-Midaina and Al-Uazair) were chosen (Figure 1). Those regions are far 76, 80 and $82 \mathrm{~km}$ respectively from the center of Basrah city. A total of one hundred and ten healthy dry ewes of Arabi sheep (37 animals for each geographic location), were divided into three different age groups: $<1$ year old, between $1-3$ years old and $>3$ years old were used. The live body weights of the young and adult ewes were $19.5-45.8 \mathrm{~kg}$ respectively. The mean maximum and minimum temperatures were $21.1^{\circ} \mathrm{C}$ and $10.4^{\circ} \mathrm{C}$ respectively. The animals in all regions were grazed ad libitum during all day on natural pasture forage with a wide range of plant, including Arundo plinii, Imperata cylindrica, alfalfa and clover.

Table 1. Primary formation about Arabi sheep.

\begin{tabular}{cccc}
\hline & Characterizes & \\
\hline Birth weight $(\mathrm{kg})$ & $4.1-4.8$ & Fleece weight $(\mathrm{kg})$ & 1.2 \\
Weaning weight $(\mathrm{kg})$ & 16.1 & Milk yield $(\mathrm{kg})$ & 52.4 \\
Maturity weight $(\mathrm{kg})$ & 40 & Lactation stage (day) & 85 \\
Daily gain $(\mathrm{g})$ & $172-150$ & Fertility (\%) & $80-55$ \\
Dressing percentage & $58.5-51.5$ & Twinning (\%) & $5-0$ \\
\hline
\end{tabular}

Al-Saigh and Al-Qas [10]. 


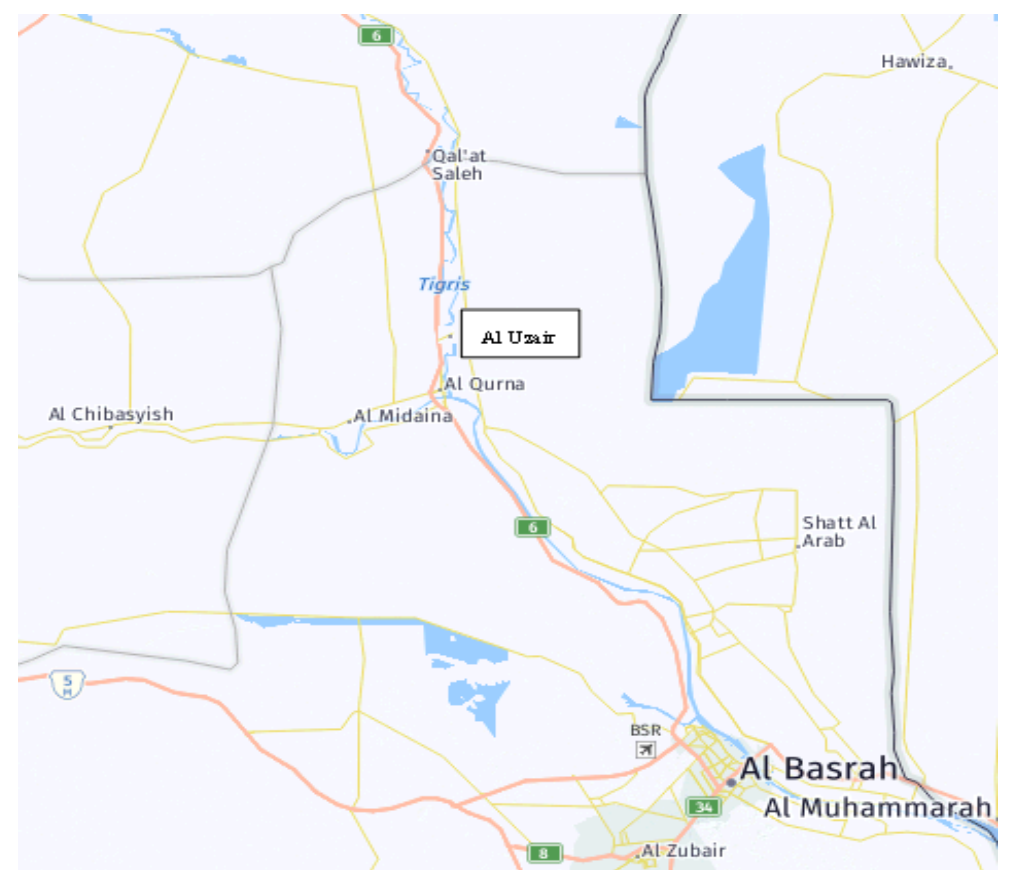

Figure 1. The map of Basrah province, presentation the three geographic locations sites in the north of Basrah center (https://www.flickr.com/places/info/55999900).

Seven $\mathrm{ml}$ of blood was collected from the jugular vein in plastic tube without anticoagulants from all animals before grazing. The blood samples were allowed to clot at room temperature and then were separated by centrifugation at 3000 rpm for 15 minutes and were frozen under $-20^{\circ} \mathrm{C}$ until analysis time.

Ascorbic acid concentration was determined by using the 2, 6-dinitrophenylhydrazine method according to [11]. The concentration of total protein and albumin were determined by using a chemical kit of the biochemical Germany Company. Fe, phosphor and cholesterol concentrations were measured by using a chemical kit of the France Biomeriex company. The glucose concentration was measured by a chemical kit of the England Plamatec company. The concentrations of Luteinizing hormone (LH), estradiol, growth hormone triiodotyronine (T3) and thyroxin (T4) were determined by using a procedure associated with the ELISA kit from Monobind Inc.-U.S.A. company.

The obtained data were analyzed statistically using SPSS [12]. Statistically significant differences were determined at the $\mathrm{P}<0.05$ level of significance.

\section{Results and Discussion}

Table 2 shows the effect of the geographic location and age on some biochemical parameters. No significant $(\mathrm{P}<0.05)$ differences in the concentration of total protein and albumin were observed among the geographic locations and age. The reason of decrease of those parameters when animals increased with age was due to the reduction in protein synthesis by the liver [13]. Similar results were also observed by Rabee et al. [8] in Kurdistan of Iraq, but, be within a high range in comparison with those recorded [14] in the marshes of south of Iraq. Ewes 
Table 2. Effect of geographic location and age on the concentrations of total protein, albumin and cholesterol in blood of Arabi ewes (Mean \pm S.E.).

\begin{tabular}{|c|c|c|c|c|c|}
\hline \multirow{2}{*}{$\begin{array}{l}\text { Geographic } \\
\text { Location }\end{array}$} & \multirow[b]{2}{*}{ Age } & \multirow[b]{2}{*}{ No. } & \multicolumn{3}{|c|}{ Biochemical parameters } \\
\hline & & & $\begin{array}{l}\text { Total protein } \\
(\mathrm{g} / 100 \mathrm{ml})\end{array}$ & $\begin{array}{l}\text { Albumin } \\
(\mathrm{g} / 100 \mathrm{ml})\end{array}$ & $\begin{array}{l}\text { Cholesterol } \\
(\mathrm{mg} / 100 \mathrm{ml})\end{array}$ \\
\hline \multirow{3}{*}{ AL-Qurna } & $<1$ year old & 12 & $4.90 \pm 0.99$ & $2.73 \pm 0.09$ & $98.15 \pm 5.43 \mathrm{a}$ \\
\hline & $1-3$ years old & 12 & $5.11 \pm \quad 0.70$ & $2.64 \pm 0.10$ & $84.43 \pm 6.77 b$ \\
\hline & $>3$ years old & 12 & $5.03 \pm 0.87$ & $1.95 \pm 0.08$ & $84.82 \pm 8.90 \mathrm{~b}$ \\
\hline \multirow[t]{2}{*}{ Mean } & & 36 & $5.02 \pm 0.65$ & $2.45 \pm 0.07$ & $89.01 \pm 7.90 \mathrm{~A}$ \\
\hline & $<1$ year old & 12 & $5.36 \pm 0.63$ & $2.83 \pm 0.12$ & $89.59 \pm 6.90 \mathrm{a}$ \\
\hline \multirow[t]{2}{*}{ Al-Midaina } & $1-3$ years old & 12 & $4.95 \pm 0.54$ & $2.50 \pm 0.08$ & $81.95 \pm 5.55 \mathrm{a}$ \\
\hline & $>3$ years old & 12 & $5.36 \pm 0.80$ & $2.47 \pm 0.08$ & $57.66 \pm 4.90 \mathrm{~b}$ \\
\hline \multirow[t]{2}{*}{ Mean } & & 36 & $5.23 \pm 0.45$ & $2.60 \pm 0.11$ & $75.90 \pm 7.09 \mathrm{AB}$ \\
\hline & $<1$ year old & 12 & $4.84 \pm 0.34$ & $2.65 \pm 0.10$ & $94.41 \pm 4.00 \mathrm{a}$ \\
\hline \multirow[t]{2}{*}{ Al-Uazair } & $1-3$ years old & 12 & $5.06 \pm 0.70$ & $2.53 \pm 0.06$ & $67.00 \pm 9.06 \mathrm{~b}$ \\
\hline & $>3$ years old & 12 & $4.71 \pm 0.86$ & $1.80 \pm 0.14$ & $39.89 \pm 4.54 \mathrm{c}$ \\
\hline Mean & & 36 & $4.86 \pm 0.60$ & $2.35 \pm 0.05$ & $65.01 \pm 6.78 \mathrm{~B}$ \\
\hline$P$ value & & & 0.397 & 0.264 & 0.000 \\
\hline
\end{tabular}

Different capital and small letters within column means a significant difference $(P<0.05)$ between geographic location and age respectively.

residing in AL-Qurna region showed a significant $(\mathrm{P}<0.05)$ increase in the concentration of cholesterol in comparison to the ewes in other geographic locations. The reason for this result may be due to some biochemical parameters, such as cholesterol, affected by nutrition level, climatic conditions and metabolic activity of animals [15] [16].

The concentration of cholesterol was decreased significantly $(P<0.05)$ in adult ewes (more than one year old) compared with younger ewes ( $<1$ year old), owing due to the fact that ewes in sexual maturity stage need to analysis cholesterol to synthesis sex estradiol hormones. Therefore, the levels of cholesterol will be reduced in the blood. This result corresponds with the other studies results [4] [15].

The data presented in Table 3 indicated that glucose concentration was a significant $(\mathrm{P}<0.05)$ increased in Al-Midaina region compared with other geographic locations, due to the difference of nutritional status of the animals [14]. For example, animals which grazed under extensive system tend to have lower glucose in their plasma compared to those grazed under intensive system [17]. So, the grazing system may have an effect on serum biochemical parameters. No significant differences in the concentrations of $\mathrm{Fe}$, phosphor and ascorbic acid were found between geographic locations. The ewes which were aged between 1 - 3 years old showed significant $(\mathrm{P}<0.05)$ increased in glucose concentration compared with other age in all geographic locations. Glucose as a major source 
Table 3. Effect of geographic location and age on the concentrations of glucose, Fe, phosphor and ascorbic acid in blood of Arabi ewes (Mean \pm S.E.).

\begin{tabular}{|c|c|c|c|c|c|c|}
\hline \multirow[b]{2}{*}{$\begin{array}{l}\text { Geographic } \\
\text { Location }\end{array}$} & \multirow[b]{2}{*}{ Age } & \multirow[b]{2}{*}{ No. } & \multicolumn{4}{|c|}{ Biochemical parameters } \\
\hline & & & $\begin{array}{c}\text { Glucose } \\
(\mathrm{mg} / 100 \mathrm{ml})\end{array}$ & $\mathrm{Fe}(\mathrm{mg} / \mathrm{L})$ & $\begin{array}{l}\text { Phosphor } \\
\text { (mg/100 ml) }\end{array}$ & $\begin{array}{c}\text { Ascorbic acid } \\
(\mathrm{mg} / \mathrm{L})\end{array}$ \\
\hline \multirow{3}{*}{ AL-Qurna } & $<1$ year old & 12 & $44.78 \pm 9.87 c$ & $1.48 \pm 0.03$ & $17.71 \pm 1.17$ & $11.57 \pm 0.34$ \\
\hline & $1-3$ years old & 12 & $88.66 \pm 7.11 \mathrm{a}$ & $1.24 \pm 0.08$ & $16.13 \pm 1.00$ & $10.64 \pm 0.23$ \\
\hline & $>3$ years old & 12 & $63.49 \pm 3.67 b$ & $1.67 \pm 0.07$ & $17.17 \pm 0.94$ & $10.72 \pm 0.67$ \\
\hline \multirow[t]{2}{*}{ Mean } & & 36 & $65.58 \pm 7.90 \mathrm{~B}$ & $1.42 \pm 0.05$ & $17.01 \pm 1.23$ & $10.97 \pm 0.54$ \\
\hline & $<1$ year old & 12 & $75.81 \pm 5.90 \mathrm{~b}$ & $1.85 \pm 0.05$ & $19.35 \pm 0.80 \mathrm{a}$ & $11.29 \pm 0.90$ \\
\hline \multirow[t]{2}{*}{ Al-Midaina } & $1-3$ years old & 12 & $91.40 \pm 6.65 \mathrm{a}$ & $1.88 \pm 0.07$ & $17.02 \pm 1.45 \mathrm{~b}$ & $10.13 \pm 0.87$ \\
\hline & $>3$ years old & 12 & $73.16 \pm 3.23 b$ & $1.43 \pm 0.09$ & $17.64 \pm 0.76 b$ & $10.68 \pm 0.55$ \\
\hline \multirow[t]{2}{*}{ Mean } & & 36 & $80.43 \pm 8.11 \mathrm{~A}$ & $1.71 \pm 0.08$ & $18.00 \pm 1.13$ & $11.03 \pm 0.73$ \\
\hline & $<1$ year old & 12 & $72.10 \pm 4.00 \mathrm{a}$ & $1.56 \pm 0.08$ & $18.73 \pm 1.00 \mathrm{a}$ & $10.75 \pm 0.60$ \\
\hline \multirow[t]{2}{*}{ Al-Uazair } & $1-3$ years old & 12 & $84.43 \pm 5.88 \mathrm{a}$ & $1.78 \pm 0.06$ & $18.34 \pm 0.85 \mathrm{a}$ & $10.62 \pm 0.43$ \\
\hline & $>3$ years old & 12 & $37.57 \pm 2.45 b$ & $1.14 \pm 0.05$ & $16.71 \pm 1.67 \mathrm{~b}$ & $9.98 \pm 0.32$ \\
\hline Mean & & 36 & $65.27 \pm 4.65 \mathrm{~B}$ & $1.49 \pm 0.03$ & $17.92 \pm 1.03$ & $10.45 \pm 0.40$ \\
\hline$P$ value & & & 0.000 & 0.456 & 0.000 & 0.254 \\
\hline
\end{tabular}

${ }^{\star}$ Different capital and small letters within column means a significant difference $(P<0.05)$ between geographic location and age respectively.

of energy for the maintenance of cell activity and as an indicator of the metabolic processes of the body, therefore it is necessary for growth and development of the mass body which are occurring in younger animals [18]. While, the decrease of glucose concentration in older animals may be due to a lower rate recovery of glucose [19]. This result agrees with the results of Rabee et al. [8].

Phosphor concentration was higher $(\mathrm{P}<0.05)$ in younger $(<1$ year old $)$ ewes compared with older ewes, this explains that the animals which aged less one year old pass in development and growth stages, including bone tissues, and phosphor is considered the most important mineral which plays a role in bone formation [20], while in younger animals, the levels of phosphor in blood higher was because of growth hormone increase re-absorption of phosphate from kidney [6]. On the other hand, the decrease of phosphor concentration in older animals may due to the reduction in phosphor absorption from the gut [19], or due to the least capacity to assimilate phosphorus from food at the age of animals rises [21]. These results were compatible with Alonso et al., [22] who recorded lower concentration phosphor in the serum of ewes aged more than two half years old.

Although, there were no significant changes in the concentration of $\mathrm{Fe}$ and ascorbic acid in serum, the values of both parameters were ranged within normal limits. Antunovic et al. [4] recorded a range for Fe concentration between 2.89 to $2.35 \mu \mathrm{mol} / \mathrm{l}$ in ewes aged $<1$ year old and $>3$ years old respectively. While, 
Howida et al. [23] recorded a range of ascorbic acid in ewes between 10.7 t0 $11.44 \mathrm{mg} / \mathrm{L}$. On the other hand, the ascorbic acid concentration was higher (not significant) in younger ewes compared with adult ewes. This result was similar to that found by Matsui [24] in cattle.

Table 4 obtained the effect of geographic location and age on some sex hormones. No significant $(\mathrm{P}<0.05)$ difference in the concentration of LH hormone was observed among geographic locations and age. The concentration of estradiol hormone increased significantly $(\mathrm{P}<0.05)$ in the blood of ewes residing in an AL-Qurna zone in comparison with other regions. As well known, the type of forage and nutrition level might have an effect on ovarian function and it is an ability secretion of sex hormones (estrogen and progesterone), where those hormones organized the reproductive performance in animals [25].

Estradiol hormone concentration was a significant $(\mathrm{P}<0.05)$ increase in blood of adult animals, especially in ewes aged between 1 to 3 years old. This may be due to that in most adult animals when arriving to sexual maturity stage, the estradiol hormone increases in the blood and ovary becomes more active (the age of sexual maturity in Arabi ewes is between 14 to 16 mouths). Furthermore, the estrus cycle could be more regularized [26].

Table 5 shows the effect of geographic location and age on some metabolic hormones. The concentration of growth hormone decreased significantly $(\mathrm{P}<$ 0.05) in the blood of ewes residing in the Al-Uazairzone in comparison with other regions. No significant $(\mathrm{P}<0.05)$ differences in concentration of $\mathrm{T} 3$ and T4 hormones were observed among the geographic locations.

Table 4. Effect of geographic location and age on concentrations of some sex hormones in blood of Arabi ewes (Mean \pm S.E.).

\begin{tabular}{ccccc}
\hline \multirow{2}{*}{$\begin{array}{c}\text { Geographic } \\
\text { location }\end{array}$} & Age & No. & \multicolumn{2}{c}{ Sex hormones } \\
\cline { 4 - 5 } & $<1$ year old & 12 & $3.29 \pm 0.05$ & $45.12 \pm 2.23 \mathrm{~b}$ \\
AL-Qurna & $1-3$ years old & 12 & $3.60 \pm 0.03$ & $49.64 \pm 3.08 \mathrm{a}$ \\
& $>3$ years old & 12 & $3.30 \pm 0.04$ & $46.61 \pm 2.09 \mathrm{~b}$ \\
Mean & & 36 & $3.40 \pm 0.02$ & $47.08 \pm 2.55 \mathrm{~A}$ \\
& $<1$ year old & 12 & $2.46 \pm 0.02$ & $41.42 \pm 3.11 \mathrm{~b}$ \\
Al-Midaina & 1 - 3 years old & 12 & $2.85 \pm 0.03$ & $46.13 \pm 2.00 \mathrm{a}$ \\
& $>3$ years old & 12 & $2.84 \pm 0.02$ & $44.32 \pm 1.98 \mathrm{c}$ \\
Mean & & 36 & $2.72 \pm 0.05$ & $43.88 \pm 2.32 \mathrm{~B}$ \\
Al-Uazair & $<1$ year old & 12 & $2.79 \pm 0.03$ & $38.65 \pm 2.44 \mathrm{~b}$ \\
& $1-3$ years old & 12 & $2.50 \pm 0.02$ & $41.01 \pm 2.00 \mathrm{a}$ \\
Mean & $>3$ years old & 12 & $2.65 \pm 0.04$ & $42.11 \pm 2.68 \mathrm{a}$ \\
P value & & 36 & $2.64 \pm 0.03$ & $40.59 \pm 1.76 \mathrm{C}$ \\
\hline
\end{tabular}

Different capital and small letters within column means a significant difference $(\mathrm{P}<0.05)$ between geographic location and age respectively. 
Table 5. Effect of geographic location and age on concentrations of some metabolic hormones in blood of Arabi ewes (Mean \pm S.E.).

\begin{tabular}{|c|c|c|c|c|c|}
\hline \multirow{2}{*}{$\begin{array}{c}\text { Geographic } \\
\text { location }\end{array}$} & \multirow[b]{2}{*}{ Age } & \multirow[b]{2}{*}{ No. } & \multicolumn{3}{|c|}{ Metabolic hormones } \\
\hline & & & $\begin{array}{c}\text { Growth hormone } \\
(\mathrm{ng} / \mathrm{ml})\end{array}$ & $\mathrm{T} 3(\mathrm{ng} / \mathrm{ml})$ & $\mathrm{T} 4$ (ng/ml) \\
\hline \multirow{3}{*}{ AL-Qurna } & $<1$ year old & 12 & $11.72 \pm 0.78 \mathrm{a}$ & $1.44 \pm 0.03 \mathrm{a}$ & $1.16 \pm 0.03 \mathrm{a}$ \\
\hline & 1 - 3 years old & 12 & $8.71 \pm 0.80 \mathrm{~b}$ & $1.14 \pm 0.03 \mathrm{~b}$ & $1.13 \pm 0.02 \mathrm{ab}$ \\
\hline & $>3$ years old & 12 & $8.83 \pm 0.65 \mathrm{~b}$ & $1.03 \pm 0.01 \mathrm{~b}$ & $1.01 \pm 0.03 \mathrm{~b}$ \\
\hline \multirow[t]{2}{*}{ Mean } & & 36 & $9.75 \pm 0.54 \mathrm{~A}$ & $1.10 \pm 0.02$ & $1.10 \pm 0.02$ \\
\hline & $<1$ year old & 12 & $10.77 \pm 0.64 \mathrm{a}$ & $1.52 \pm 0.01 \mathrm{a}$ & $1.20 \pm 0.01 \mathrm{a}$ \\
\hline \multirow[t]{2}{*}{ Al-Midaina } & 1 - 3 years old & 12 & $8.96 \pm 0.43 b c$ & $1.01 \pm 0.02 \mathrm{~b}$ & $1.02 \pm 0.04 \mathrm{~b}$ \\
\hline & $>3$ years old & 12 & $9.30 \pm 0.87 \mathrm{~b}$ & $0.87 \pm 0.02 b$ & $0.90 \pm 0.01 \mathrm{c}$ \\
\hline \multirow[t]{2}{*}{ Mean } & & 36 & $9.67 \pm 0.54 \mathrm{~A}$ & $1.14 \pm 0.03$ & $1.04 \pm 0.04$ \\
\hline & $<1$ year old & 12 & $9.77 \pm 0.54 \mathrm{a}$ & $1.94 \pm 0.06 \mathrm{a}$ & $1.00 \pm 0.01 \mathrm{a}$ \\
\hline \multirow[t]{2}{*}{ Al-Uazair } & 1 - 3 years old & 12 & $7.01 \pm 0.45 b$ & $1.51 \pm 0.03 \mathrm{~b}$ & $0.91 \pm 0.01 \mathrm{ab}$ \\
\hline & $>3$ years old & 12 & $8.01 \pm 0.90 \mathrm{~b}$ & $0.92 \pm 0.04 \mathrm{c}$ & $0.86 \pm 0.03 \mathrm{~b}$ \\
\hline Mean & & 36 & $8.26 \pm 0.93 \mathrm{~B}$ & $1.45 \pm 0.07$ & $0.93 \pm 0.02$ \\
\hline$P$ value & & & 0.000 & 0.000 & 0.000 \\
\hline
\end{tabular}

Different capital and small letters within column means a significant difference $(\mathrm{P}<0.05)$ between geographic location and age respectively.

Concentrations of growth hormone, T3 and T4 hormones were significant ( $\mathrm{P}$ $<0.05$ ) increase in younger animals ( $<1$ year old) compared with adult animals. The reason of growth hormone increase can be attributed to the fact that growth hormone is an anabolic hormone which stimulates skeletal bone formation and elevation of protein synthesis and those metabolism processes are higher in younger animals and decline with a rise of age [27]. T3 and T4 concentration increase were probably related to the elevation metabolism rates in younger animals than older once [15] and this biological activity needs more secretion of metabolic hormones such as $\mathrm{T} 3$ and T4. These results agree with the results of [28] [29].

\section{Conclusion}

From the present study, it can be concluded that the geographic locations in the south of (north of Basrah province) and age of Arabi ewes have effect on some biochemical parameters and hormones, and this may be due to the variety of cover plant in this zone of Iraq.

\section{Conflicts of Interest}

The authors declare no conflicts of interest regarding the publication of this paper.

\section{References}

[1] Majid, S.A., Al-Murani, W.K., Alkass, J.E. and Al-Rawi, A.A. (2003) Iraqi Country 
Report to the FAO, for the State of the World. Animal Genetic Resources, FAO, Rome.

[2] Juma, K.H. and Alkass, J.E. (2000) Sheep in Iraq. The Arab Center for the Studies of Arid Zones and Dry Lands (ACSAD). Damascus.

[3] Huszenicza, G.Y., Kulcsar, M. and Rudas, P. (2002) Clinical Endocrinology of Thyroid Gland Function in Ruminants. Veterinary Medicine, 47, 199-210.

[4] Antunovic, Z., Šperanda, M. and Steiner, Z. (2004) The Influence of Age and the Reproductive Status to the Blood Indicators of the Ewes. Arch. Tierz., Dummerstorf, 47, 265-273.

[5] Njidda, A.A., Shuai'bu, A.A. and Isidahomen, C.E. (2014) Hematological and Serum Biochemical Indices of Sheep in Semi-Arid Environment of Northern Nigeria. Global Journal of Science Frontier Research: Agriculture and Veterinary, 14, 1-8.

[6] Kaneko, J.J., Harvey, J.W. and Bruss, M.L. (2008) Clinical Biochemistry of Domestic Animals. 6th Edition, Academic Press, San Diego (USA), 916 p.

[7] Mcdowell, L.R. (1985) Nutrition of Grazing Ruminants in Warm Climates. Academic Press, New York.

[8] Rabee, A.S.O., Araz, O.B. and Hawar, M.H.Z. (2014) Factors Affecting Some Hematology and Serum Biochemical Parameters in Three Indigenous Sheep Breeds. Advances in Life Science and Technology, 21, 56-62.

[9] Jezek, J., Klopcic, M. and Klinkon, M. (2006) Influence of Age on Biochemical Parameters in Calves. Bulletin of the Veterinary Institute in Pulawy, 50, 211-214.

[10] Al-Saigh, M.N.R. and Al-Qas, J.A. (1999) Sheep and Goats Production. In: Chapter II: The Breeds of Sheep and Goats and the Classification Methods, Dar Alhakma-University of Basrah, 27-52.

[11] Roe, J.H. and Oesterling, H.J. (1944) The Determination of Dihydro Ascorbic Acid and Ascorbic Acid in Plant Tissues by the 2,4-Dinitrophenylhydrazine Method. The Journal of Biological Chemistry, 152, 511-517.

[12] SPSS (2013) Statistical Packages of Social Sciences. Version 9.00.

[13] Dubreuil, P., Arsenault, J. and Bélanger, D. (2005) Biochemical Reference Ranges for Groups of Ewes of Different. Veterinary Record, 156, 636-638. https://doi.org/10.1136/vr.156.20.636

[14] Al-Fartosi, Kh.G., Talib, Y.J. and Ali, Sh. (2010) Comparative Study of Some Serum Biochemical Parameters of Cattle and Sheep of the Marshes in the South of Iraq. Archives of Al-Qadisiyah Journal of Veterinary Medicine Sciences, 9, 78-84.

[15] Carlosa, M.M.L., Leiteb, J.H.G.M., Chavesb, D.F., Valeb, A.M., Façanhab, D.A.E., Meloc, M.M. and Soto-Blancoc, B. (2015) Blood Parameters in the Morada Nova Sheep: Influence of Age, Sex and Body Condition Score. The Journal of Animal \& Plant Sciences, 25, 950-955.

[16] Shumaila, K., Bhutta, A.M., Khan, B.A., Durrani, S., Ali, M., Ali, M. and Iqbal, F. (2012) Effect of Age and Gender on Some Blood Biochemical Parameters of Apparently Healthy Small Ruminants from Southern Punjab in Pakistan. Asian Pacific Journal of Tropical Biomedicine, 2, 304-306. https://doi.org/10.1016/S2221-1691(12)60028-8

[17] Gbolabo, O.O., Florence, O.O., Timothy, M.S. and Aliyu, I.M. (2015) Parameters Influencing Hematological, Serum and Biochemical References in Livestock Animals under Different Management Systems. Open Journal of Veterinary Medicine, 5, 181-189. https://doi.org/10.4236/ojvm.2015.58025 
[18] Sastradipradja, D. (1998) Glucose in Ruminants. A Review. Ulas Balik, 5, 59-65.

[19] Radostits, O.M. (2000) Veterinary Medicine. A Textbook of the Diseases of Cattle, Sheep, Pigs, Goats and Horses, 9th Edition.

[20] Kebreab, E. and Vitti, D. (2005) Mineral Metabolism. In: Dijkstra, J., Forbes, J.M. and France, J., Eds., Quantitative Aspects of Ruminant Digestion and Metabolism, 2nd Edition, CAB Int., Wallingford, 469-486.

[21] Blood, D.C. and Radostits, O.M. (1993) Medcina Veterinaria. 7th Edition, McGrawHill, Madrid, 1293-1294.

[22] Alonso, A.J., Teresa, R.D., Garcia, M., Gonzales, J.R. and Vallejo, M. (1997) The Effects of Age and Reproductive Status on Serum and Blood Parameters in Merino Breed Sheep. Zentralblatt für Veterinärmedizin, 44, 223-231. https://doi.org/10.1111/j.1439-0442.1997.tb01104.x

[23] Howida, M.A., Abd-El-Rahman and Maha, A. (2013) Impact of Ascorbic Acid and Probiotics for Improvement of Concentration Rate of Ewes during Summer Season. Assiut Veterinary Medical Journal, 59, 21-31.

[24] Matsui, T. (2012) Vitamin C Nutrition of Cattle. Asian-Australasian Journal of Animal Sciences, 25, 597-605.

[25] Chilliard, Y., Delavaud, C. and Bonnet, M. (2005) Leptin Expression in Ruminants: Nutritional and Physiological Regulations in Relation with Energy Metabolism. Domestic Animal Endocrinology, 29, 3-22. https://doi.org/10.1016/j.domaniend.2005.02.026

[26] Forest, M.G. and Levasseur, M.C. (1993) Puberty: Reproduction in Mammals and Man. Ellipses, Paris, 566-587.

[27] Bassett, J.M., Weston, R.M. and Morgan, J.P. (1971) Dietary Regulation of Plasma Insulin and Growth Hormone Concentrations in Sheep. Australian Journal of Biological Sciences, 24, 321-330. https://doi.org/10.1071/BI9710321

[28] Novoselec, J., Antunovic, Z., Šperanda, M., Steiner, Z. and Speranda, T. (2009) Changes of Thyroid Hormones Concentration in Blood of Sheep Depending on Age and Reproductive Status. Italian Journal of Animal Science, 8, 208-210. https://doi.org/10.4081/ijas.2009.s3.208

[29] Todini, L. (2007) Thyroid Hormones in Small Ruminants: Effects of Endogenous, Environmental and Nutritional Factors. Animal, 1, 997-1008. https://doi.org/10.1017/S1751731107000262 